\title{
Using water chemistry to define ecological preferences within the moss genus Scorpidium, from Wales UK.
}

Jonathan Graham ${ }^{1}$, Gareth Farr ${ }^{2}$, Lars Hedenäs ${ }^{3}$, Aurelie Devez ${ }^{4} \&$ Michael J Watts ${ }^{4}$.

12 Cross Road, Whittlesey, Cambridgeshire, PE7 1LX, UK

${ }^{2}$ British Geological Survey, Cardiff University, Park Place, Cardiff, CF10 3AT, UK

${ }^{3}$ Swedish Museum of Natural History, Department of Botany Box 50007, SE -1040 05 Stockholm, Sweden

${ }^{4}$ British Geological Survey, Nicker Hill, Keyworth, Nottingham, NG12 5GG, UK

Corresponding author email: jonathan.graham@ntlworld.com 


\section{Abstract}

2 Three Scorpidium species; S. scorpioides, S. cossonii and S. revolvens are often associated with habitats of high conservation value. This is the first attempt to define the chemical niches of these Scorpidium species in Wales (UK) and allows us to compare to earlier European datasets. Water chemistry from sixteen locations was analysed from direct squeezing of mosses from a total of 77 spots and the principal water supply, e.g. springs and seepages. Spherical k-means clustering suggests there are two distinct groups in the dataset; one characterised by S. cossonii and another by S. revolvens, associated with differences in $\mathrm{pH}$ and Electric Conductivity (EC) of the habitat. The Wales habitats have higher $\mathrm{pH}$ and EC than Scandinavian habitats of the species, which could potentially be a result of different pollution histories or species compositions of the areas, the latter leading to different realised niches along the mineral poor to rich gradient. It is hoped that a better understanding of the chemical niches will support site managers and environmental regulators to make evidence-based decisions to protect these species and their habitats.

Keywords: cluster analysis, petrifying springs, Habitats Directive

\section{Introduction}

Humans have long since influenced European nature both directly, through exploitation and management of different resources (e.g., Antrop, 2004; Kaplan et al., 2009; Price, 2000) and indirectly, as shown by the ongoing climate warming (Met Office, UK's National Meteorological Service; https://www.metoffice.gov.uk/; accessed 2019.01.05). To protect our environment, including its biodiversity, we need methods and indicators that provide warnings when we come close to irreparable damage. A relatively rare European habitat that could potentially be negatively influenced by climate change-related effects, such as higher temperatures and increased evapotranspiration on the one hand, and increased precipitation on the other, is the European Habitats \& Species Directive habitat 'H7220 Petrifying springs with tufa formation (Cratoneurion)'. Member states, including the 
UK at the time of writing, are required to report on the conservation status of these habitats to the European Commission.

Species of the genus Scorpidium (Calliergonaceae) are often, but not exclusively associated with European Habitats \& Species Directive habitat H7220, and Scandinavian studies (Kooijman \& Hedenäs, 1991; Hedenäs \& Kooijman, 1996; Tahvanainen, 2004) suggest that they are useful as indicators of its status. Scorpidium includes three species, S. scorpioides (Hedw.) Limpr., S. cossonii (Schimp.) Hedenäs and S. revolvens (Sw.ex Anonymo) Rubers (Hedenäs, 1989). The genus occurs globally from temperate to arctic areas and in both the northern and southern hemispheres (Table 1). Water chemistry has been used as a useful tool to distinguish habitat preferences within the genus in Scandinavia (Kooijman \& Hedenäs, 1991). This methodological approach has been applied in different ecological studies of aquatic bryophytes (Kooijman et al., 1994; Ceschin et al., 2012) and its possible applicability to sites in the UK with Scorpidium species is of interest to both environmental regulators and site managers for whom an improved understanding of the habitat requirements, and risks, will better inform decisions regarding management and conservation of these sites.

Field and laboratory observations (Kooijman \& Hedenäs, 1991; Tahvanainen, 2004) show that S. revolvens occurs in a much narrower range of $\mathrm{pH}$ and conductivity than S. scorpioides and S. cossonii which are more often associated with calcium-rich spring-influenced habitats. Sites with S. scorpioides and S. cossonii are characterised by relatively high pore water Ca concentrations (Mettrop et al., 2018) while S. revolvens is absent from calcium-rich sites (Hedenäs, 2003a). Acidification and eutrophication can have a negative effect and has resulted in the decrease of $S$. scorpioides populations in the Netherlands (Kooijman, A. 1992 and Kooijman \& Westhoff, 1995). A recent study of Dutch sites (Paulissen, et. al., 2016) found that rich fens, i.e., mineral-rich fens that are often, but not always species-rich and include certain indicator species, such as S. cossonii (Joosten et al., 2017; Rydin et al., 1999), are at risk of rapid transition to poor fens by increased deposition of reduced nitrogen. Increased ammonium levels are shown to be directly toxic to Scorpidium, while Sphagnum was not 
affected. In addition, nitrogen (in particular nitrate) can indirectly influence moss growth through promoting vascular plants and Covuer et al. (2016) has highlighted the negative impact of eutrophication (nitrite and particularly phosphate) on the H7220 habitat in Belgium. Scorpidium scorpioides and S. cossonii sites in Sweden and the Netherlands are shown to be Ca-rich and Fe-poor with low associated P-availability (Mettrop et al., 2018); this further highlights the potential vulnerability of these sites to the process of eutrophication. Growth experiments comparing Canadian and Dutch S. scorpioides (Vitt et. al., 1993) found that Canadian plants respond best when grown in extreme-rich fen waters, while plants from the Netherlands respond best in waters from moderaterich fens and in nutrient enhanced conditions. These authors suggested that this could be a result of ecotypic differentiation.

All these studies show that water chemistry is a critical factor affecting Scorpidium species and has important implications for the conservation of rich fens. Here we present the first Wales (taken to represent UK) dataset of water chemistry characterising the different chemical niches of the three Scorpidium species and compare this data set with data previously compiled in Sweden (Kooijman \& Hedenäs, 1991). We ask whether all three species occur under similar water chemistry conditions at localities in Wales, and evaluate whether conditions differ between Wales and Sweden.

\section{Materials and methods}

Scorpidium sites were identified from wetlands within designated sites (e.g. Special Areas of Conservation, National Nature Reserves), from the British Bryological Society (BBS) database and from expert local knowledge. The location, site extent, altitude and geology, as well as other characteristics and sampling years for the 16 sites included within this study are shown in Figure 1 with other key study areas in Sweden, the Republic of Ireland, the Netherlands, Denmark and Finland illustrated on the inset map. Bryophytes commonly associated with springs and flushes (such as Scorpidium species) can often occur towards the margins of areas of flushed vegetation or as part of hummocky vegetation 
reflect this, water samples were collected both directly from the main water supply and by squeezing stands of the three Scorpidium species that represented the different habitats found by visual inspection at each locality. Seventy seven samples were collected from 16 sites with a range of between 1 and 9 samples per site reflecting both size and structural complexity of individual sites. Water chemical sampling was undertaken in January 2015 and 2016.

First a sample was obtained from as close to the water source as possible. If the flow was too diffuse to allow collection directly into a bottle, we used a $50 \mathrm{ml}$ syringe to collect water. Field parameters with temperature $\left({ }^{\circ} \mathrm{C}\right), \mathrm{pH}$ and electrical conductivity, $(\mu \mathrm{s} / \mathrm{cm})(\mathrm{EC})$ were measured using a ${ }^{ } \mathrm{YSI} \mathrm{I}^{\mathrm{TM}}$ Professional' field meter. Samples for spring water were filtered on site using a $0.45 \mu \mathrm{m}$ filter and stored in two $30 \mathrm{~mL}$ Nalgene bottles. For sampling of individual stands of Scorpidium species, samples were collected as described and the moss was squeezed using a stainless steel potato ricer into a stainless steel jug, allowing sufficient depth of water from which to measure field parameters. Many of these samples, from now onwards called 'moss water', were too turbid to filter in the field. In these cases, water samples were collected in two $30 \mathrm{~mL}$ Nalgene bottles and returned to the lab to settle and be filtered through a $0.45 \mu \mathrm{m}$ single use membrane filter (Sartorius-Minisart ${ }^{\circledR}$ ) into $30 \mathrm{~mL}$ Nalgene bottles stored at $1-5^{\circ} \mathrm{C}$ prior to conductivity and IC analysis. The sample for ICP-MS analysis was fixed in $1 \% \mathrm{HNO}_{3}$ and stored at $1-5^{\circ} \mathrm{C}$ (see below). $\mathrm{pH}$ and alkalinity measurements were undertaken on unfiltered un-acidified samples. $\mathrm{pH}$ was measured in the field and also in the lab, potentiometrically by immersing a combined multi-probe electrode (XC-161) into the solution. Titration was performed using $0.005 \mathrm{M}$ sulphuric acid prepared from VWR Prolabo Convol Normadose $0.1 \mathrm{~N}$ solution made up to volume with freshly prepared MilliQ. Analysis of major anions, including $\mathrm{Ca}^{2+}, \mathrm{Na}^{+}, \mathrm{Mg}^{2+}, \mathrm{K}^{+}, \mathrm{SO}_{4}{ }^{2-}$, $\mathrm{Cl}^{-}, \mathrm{HCO}_{3}^{-} \mathrm{F}^{-}, \mathrm{NO}_{2}^{-}, \mathrm{Br}^{-}, \mathrm{NO}_{3}{ }^{-}$and $\mathrm{HPO}_{4}{ }^{2-}$, were undertaken on a Dionex ICS5000 Ion Chromatograph system (S/N 10060887) controlled by the Chromeleon Software (version 7). Ionic balances were performed for each sample. Fifty seven major and trace elements in the core waters were analysed on an Agilent $7500 \mathrm{cx}$ series, quadrupole inductively coupled plasma mass spectrometer (ICP-MS) with an ORS, in combination with a CETAC autosampler. The ICP-MS instrument was calibrated at the 
beginning of every analytical run using at least three standards and a blank for each trace element and three standards and a blank for major elements.

103

104

Relatively pure stands of Scorpidium species occurring within each site were identified and selected in the field. Following squeezing to obtain a moss water sample the squeezed moss sample was collected and dried. Once dried, the sample was carefully examined and the small percentage of other bryophytes sometimes present estimated and recorded. For these occasional mixed stands, associated species have been annotated against the relevant chemical analysis. All samples were retained as a reference collection and all S. cossonii and S. revolvens specimens were checked microscopically following Hedenäs (1989). Other species occurring at sites were also recorded with an estimate of abundance using the DAFOR scale. Using ArcView, a Geographical Information System (GIS), elevation to the nearest 5 maOD (above ordnance datum) and geological information (British Geological Surveys' DigiMap' 1:50,000 scale bedrock and superficial mapping) was assigned to each site.

\section{Statistical methodology}

Four moss water chemistry parameters, $\mathrm{EC}, \mathrm{pH}, \mathrm{Ca}$ and $\mathrm{HCO}_{3}{ }^{-}$, were compared between Wales and Sweden for each of the three species. We used a preliminary ANOVA to check that the residuals were approximately normally distributed. This being the case, we compared our data sets for Wales and Sweden using ANOVA in the program STATISTICA 13 (Dell Inc., 2015).

From the full water chemistry dataset for Wales, only major ions and trace elements with average concentration $>0.2 \mathrm{mg} / \mathrm{L}$ were considered relevant for statistical analysis. This included all the major ions and the trace element $\mathrm{Mn}$. In addition to standard calculations of standard deviation (SD), standard error (SE), t-test (t), full statistical analysis of Welsh data was undertaken using a spherical kmeans clustering computer programme (Hill et. al., 2013).

\section{Results}


Following Kooijman \& Hedenäs (1991), elevation and water chemistry data (moss water) of 124 samples from Sweden were compared against 77 samples from Wales. Water chemistry comprised seven major ions $\left(\mathrm{Ca}, \mathrm{Mg}, \mathrm{HCO}_{3}^{-}, \mathrm{SO}_{4}{ }^{2-}, \mathrm{Cl}^{-}, \mathrm{Na}, \mathrm{K}\right)$. The same relationship between the three Scorpidium species and water chemistry (as described by Kooijman \& Hedenäs, 1991) was seen with Welsh data, where S. revolvens occurs in a much narrower range of $\mathrm{pH}$ and conductivity than the other 2 species. Figure 2 shows this relationship between $\mathrm{pH}$ and EC for all Swedish and Welsh samples.

Swedish and Welsh data show ecological separation of S. cossonii and S. revolvens in terms of water chemistry. Scorpidium cossonii is associated with water that has significantly higher concentrations of $\mathrm{HCO}_{3}{ }^{-}, \mathrm{pH}, \mathrm{Ca}, \mathrm{Mg}$ and $\mathrm{EC}$ while conversely, S. revolvens is associated with significantly lower concentrations of these. Although both Swedish and Welsh data shows clear ecological separation of S. cossonii and S. revolvens in terms of water chemistry, Welsh Scorpidium sites occur at higher, pH (all species) and EC (S. revolvens), levels than found at Swedish sites (Table 2).

\section{Statistical Results for Welsh sites}

Statistical analysis was undertaken on 77 water samples from 16 Welsh sites for $\mathrm{pH}$, EC, major ions and trace elements occurring at a mean concentration $>0.2 \mathrm{mg} / \mathrm{L}$. Samples comprised both flush water and moss water. Moss water samples comprise a pure bryophyte species stand or occasionally up to as many as five separate bryophyte species. A summary of moss water quality data is provided in Table 3. There are significant differences between the moss water chemistry of Scorpidium cossonii and Scorpidium revolvens sites (SE and t value) with respect to $\mathrm{HCO}_{3}{ }^{-} \mathrm{pH}, \mathrm{Ca}, \mathrm{Mg}$ and EC. These conclusions further support the findings of Kooijman \& Hedenäs (1991). We could not demonstrate statistical difference between moss and flush water for Scorpidium species.

\section{Statistical species clustering}

Using a spherical k-means clustering analysis of combined site and water chemistry data, Welsh sites were separated into two and three species clusters. The most distinct separation was found with a 

these two groups is provided by Table 5 .

152

Group 1 (S. cossonii) is associated with water with higher concentrations of $\mathrm{Ca}, \mathrm{Mg}$, frequent Palustriella falcata, Campylium stellatum, Bryum pseudotriquetrum, occasional Scorpidium scorpioides and are never associated with Sphagna. Group 2 (S. revolvens) is associated with water with lower concentrations of $\mathrm{Ca}, \mathrm{Mg}$, more closely associated with Sphagna (most typically $\mathrm{S}$. denticulatum) and occasional Sarmentypnum exannulatum.

\section{Discussion}

The Scorpidium habitats in Wales fit within the habitat parameter ranges reported for the species (Table 1) and, like in Scandinavia (Kooijman \& Hedenäs, 1991), the habitats of S. cossonii and S. revolvens differ from each other in their water chemistry. The latter is further reflected in that many Welsh group I sites are associated with historic lime quarrying activities and can be large in extent (0.06-0.08 ha) while Welsh Group 2 sites tend to be natural and typically small in extent (0.0004-0.008 ha). Interestingly, all three Scorpidium species occur at higher $\mathrm{pH}$ and sometimes EC (S. revolvens) in Wales than in Sweden. Our information cannot fully explain this discrepancy, but several factors can potentially be involved. The Swedish localities have a somewhat lower buffering capacity than the Welsh ones (e.g., less $\mathrm{Ca}$ and $\mathrm{HCO}_{3}{ }^{-}$, Table 2). Less well-buffered Scorpidium sites are more sensitive to acidification (Kooijman, 2012) and potentially eutrophication (e.g., in relation to associated Pavailability as highlighted by Mettrop et al., 2018) and possibly less well-buffered Welsh sites have vanished due to higher atmospheric pollution levels in Wales than in Sweden. If the sites in Wales and Scandinavia have different species compositions, potentially resulting from different species pools or climates, this could also skew the realised niches of the Scorpidium species in different directions along the mineral poor to rich gradient (cf., Shaw, 1985; Stieperaere et al., 1997). Differences in geology or genetic set-up of the species (see Hedenäs, 2009; Kophimai, 2013) between the two areas could also affect the habitat preferences of the species. However, studies of ITS and $r p / 16$ suggest that $S$. cossonii 
samples from the British Isles do not differ genetically from populations in Scandinavia (Hedenäs, 2009). Obviously, more detailed studies are required to find out which explanation or combination of explanations are most likely. The cluster analysis of associated bryophytes shows that $S$. cossonii, together with S. scorpioides, and S. revolvens belong to two rather different fen moss communities. The respective species associations lend statistical support to earlier observations on the ecology of the Scorpidium species in Britain (as summarised by Blockeel 2000). The corresponding water chemistry data suggests that this factor is likely decisive in explaining which species occur in the respective associations. However, the present analysis is limited to Welsh sites and to verify the general validity of the two moss associations identified, the results should be compared with the species growing with Scorpidium at sites across a wider geographical area.

This study could not demonstrate a statistical difference between moss and flush water for the Scorpidium species. In hindsight, we believe that both more frequent and detailed water sampling are required to fully test if temporal and microtopographic site variation explain this lack of difference. An investigation of the water chemistry of Scorpidium-rich fens in Finland (Tahvanainen, 2005) found variation in $\mathrm{pH}$ only at a microtopographic level (between capillary-held and surface water), and that this variation had a diurnal pattern probably relating to production and consumption of $\mathrm{CO}_{2}$.

\section{Conclusions}

- This study confirms the findings of Kooijman \& Hedenäs (1991) that two species of Scorpidium (S. cossonii and S. revolvens) occupy different ecological niches in terms of water chemistry and that their methodology is repeatable.

- The ecology of Welsh Scorpidium sites is better understood following statistical cluster analysis of associated bryophytes species.

- This is the first detailed water chemistry dataset for Wales (and the UK) Scorpidium sites and will support environment managers in condition monitoring and conservation of Scorpidium sites. 
201

202

203

204

205

206

207

208

209

210

211

212

213

214

215

216

217

218

219

220

221

222

223

224

225

226

227

228

229

230

The authors would like to thank the following: Sam Bosanquet, Peter S Jones, Jonathan Saville and Julie Creer from Natural Resources Wales. David Schofield, British Geological Survey for funding the chemical analysis and Dr Mark Hill for help with data analysis using spherical k-means. Gareth Farr, Aurelie Devez and Michael Watts publish with the permission of the executive director, British Geological Survey, NERC. Annemieke Kooijman allowed us to use Swedish data collected jointly with Lars Hedenäs. Comments by reviewers and A. Vanderpoorten significantly improved the paper.

\section{Declaration of interest statement}

No potential conflict of interest was reported by the authors.

\section{Funding details}

This work is in part the result of an initial commercial project for Natural Resources Wales supplemented with British Geological Survey (Welsh office) science funding for additional chemical analysis. The authors contributed their own time for additional survey, sampling and preparation of this manuscript.

\section{References}

Antrop, M. 2004. Landscape change and the urbanization process in Europe. Landscape and Urban Planning 67, 9-26.

Blockeel, T. L. 2000. The identification of Drepanocladus revolvens and D. cossonii, and their distribution in Britain and Ireland. Bulletin of the British Bryological Society, 75, 32-40.

Ceschin S., Aleffi M., Bisceglie S., Savo V., Zuccarello V., 2012. Aquatic bryophytes as ecological indicators of water quality in the Tiber basin, Italy. Ecological Indicators 14(1), 74-81.

Covuer et al., 2016. Factors affecting the presence and the diversity of bryophytes in the petrifying sources habitat (7220) in Wallonia and the Brussels Capital Region, Belgium.

Dell Inc. 2015. Dell Statistica (data analysis software system), version 13. software.dell.com.

Farr, G., Graham, J \& C, Stratford, C. 2014 Survey, characterisation and condition assessment of Palustriella dominated springs 'H7220 petrifying springs with tufa formation (Cratoneurion) in 
Wales. NERC, 211pp. (Natural Resources Wales Evidence Report No. 136, WL/NEC03832/13_14/T6, OR/14/043) (Unpublished).

Graham, J \& Farr, G. 2014 Petrifying springs in Wales. Field Bryology (112). 19-29.

Hedenäs, L. 1989. The genera Scorpidium and Hamatocaulis, gen. nov. in northern Europe. Lindbergia, 15, 8-36.

Hedenäs L. 1999. Altitudinal distribution in relation to latitude; with examples among wetland mosses in the Amblystegiaceae. Bryobrothera, 5, 99-115.

Hedenäs, L. 2003a. The European species of the Calliergon-Scorpidium-Drepanocladus compex, including some related or similar species. Meylania (Newsletter of the Swiss association of Bryology and Lichenology), 28, 1-116.

Hedenäs, L. 2003b. Amblystegiaceae (Musci). Flora Neotropica Monograph, 89, 1-107.

Hedenäs, L. 2009. Relationships among arctic and non-arctic haplotypes of the moss species Scorpidium cossonii and Scorpidium scorpioides (Calliergonaceae). Plant Systematics \& Evolution, 277, 217-231.

Hedenäs L. 2014. Calliergonaceae. In: Flora of North America Editorial Committee, ed. Flora of North America, north of Mexico. Volume 28. Bryophyta, Part 2. New York \& Oxford: Oxford University Press, pp. 384-403.

Hedenäs, L. \& Kooijman, A. 1996. Förändringar i rikkärret SV om Mellansjön (Mellanslättsjön) i Västergötland. Svensk Botanisk Tidskrift 90: 113-121.

Joosten, H., Couwenberg, J., Moen, A. \& Tanneberger, F. 2017. Mire and peatland terms and definitions in Europe. In: Joosten, H. Tanneberger, F. \& Moen, A. (eds). Mires and peatlands of Europe. Stuttgart: E. Schweizerbart'sche Verlagsbuchhandlung (Nägele u. Obermiller), pp. 65-96.

Hill, M.O., Harrower, C.A. \& Preston, C.D. 2013.Spherical k-means clustering is good for interpreting multivariate species occurrence data. Methods in Ecology and Evolution, 4, 542-551.

Kaplan, J.O., Krumhardt, K.M. \& Zimmermann, N. 2009. The prehistoric and preindustrial deforestation of Europe. Quaternary Science Reviews 28, 3016-34.

Kooijman, A. 2012. 'Poor rich fen mosses': atmospheric N-deposition and P-eutrophication in baserich fens. Lindbergia 35, 42-52.

Mettrop, I.S., Neijmeijer, T., Cusell, C., Lamers, P.M., Hedenäs, L. \& Kooijman, A. 2018. Calcium and iron as key drivers of brown moss composition through differential effects on phosphorus availability, Journal of Bryology.

Kooijman, A. 1992. The decrease of fen rich bryophytes in the Netherlands. Biological Conservation, 59, 139-143.

Kooijman, A. \& Hedenäs, L. 1991. Differentiation in habitat requirements within the genus Scorpidium, especially between S. revolvens and S. cossonii. Journal of Bryology, 16, 619-627. 
Kooijman A.M., Beltman B. \& Westhoff V. 1994 Extinction and reintroduction of the bryophyte Scorpidium scorpioides in a rich-fen spring site in the Netherlands. Biological Conservation, 69, 87-96

Kooijman, A.M \&Westhoff, V. 1995. Variation in habitat factors and spceices composition of Scorpidium scorpiodies communtiies in NW-Europe. Vegetatio, 117, 133-150

Kooijman, A.M. 2012. 'Poor rich fen mosses': atmospheric N-deposition and P-eutrophication in base-rich fens. Lindbergia, 35, 42-52.

Kophimai Y. 2013. Population genetics of the fen specialist moss Scorpidium cossonii in northeastern Switzerland (PhD thesis). Bern: Universität Bern.

Paulissen, M.P.C.P., Bobbink, R., Robat, S.A.\& Verhoeven, J.T.A. 2016. Effects of Reduced and Oxidised Nitrogen on Rich-Fen Mosses: a 4-Year Field Experiment. Water Air Soil Pollut,227, 18 (p. 114).

Price T.D. (ed.). 2000. Europe's first farmers. Cambridge: Cambridge University Press.

Rydin, H., Sjörs, H. \& Löfroth, M. 1999. Mires. Acta Phytogeographicaca Suecica 84, 91-110.Shaw, J. 1985. The relevance to ecology of species concepts in bryophytes. Bryologist 88, 199-206.

Stieperaere, H., Heylen, O. \& Podoor, N. 1997. Differences in species composition of the bryophyte layer of some Belgian and Dutch pinewoods with and without the invading hepatic Lophocolea semiteres (Lehm.) Mitt. Journal of Bryology 19, 425-434.

Tahvanainen, T. 2004. The growth of Scorpidium revolvens in relation to calcium and magnesium. Lindbergia, 29, 123-128.

Tahvanainen, T. 2005. Diversity of water chemistry and vegetation of mires in the Kainuu region, middle boreal Finland. PhD dissatations in biology No. 33, University of Joensuu.

Vitt, D.H, Wirdum, G.V, Halsey,L \&Zoltai, S. 1993. The Effects of Water Chemistry on the Growth of Scorpidium scorpioides in Canada and The Netherlands. Bryologist, 96, 106-111 


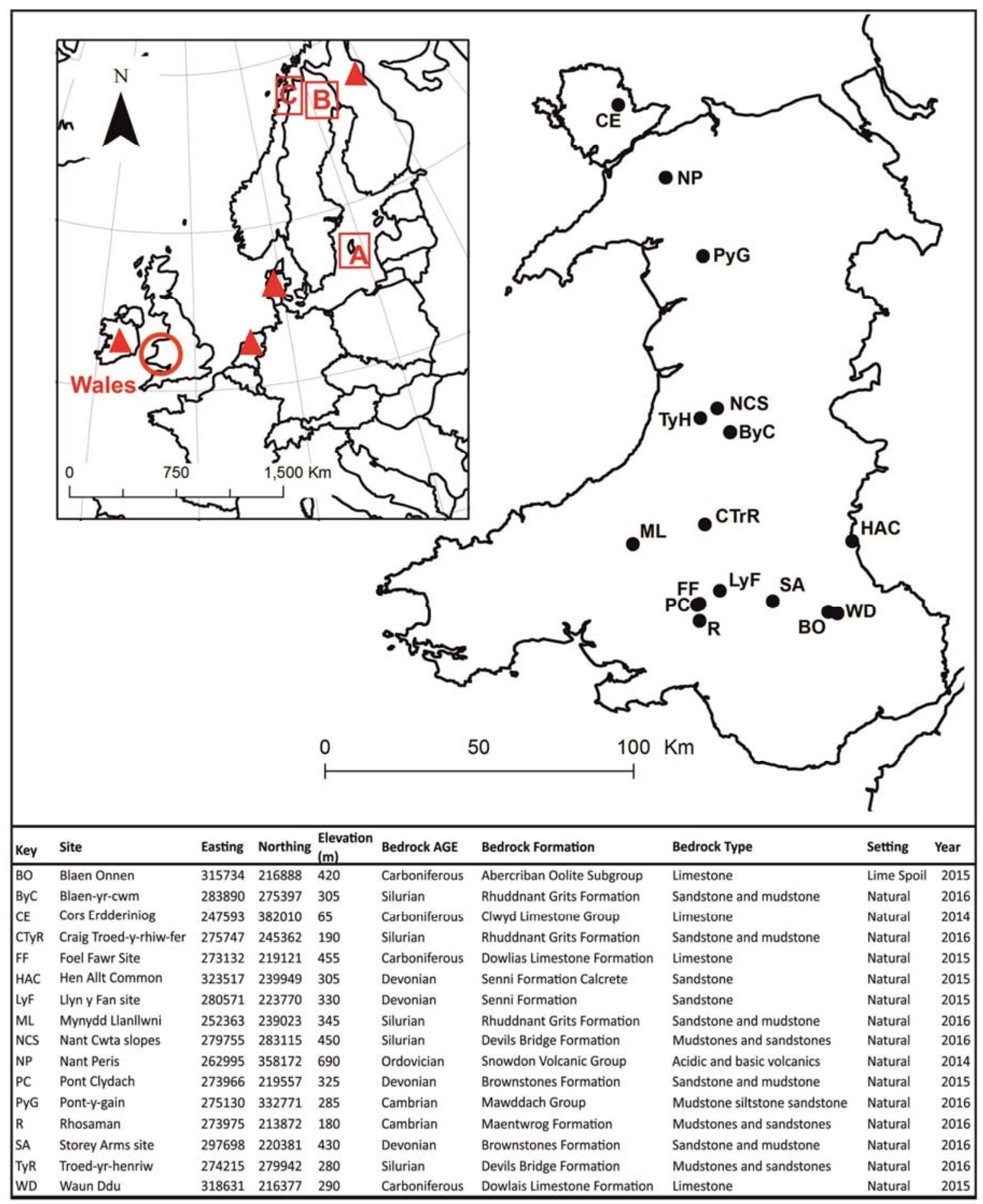

Figure 1. Sample locations: Welsh sites, elevation, geology, setting and sampling year. Inset: previous studies in Sweden represented by squares labelled A, B and C (Koojiman \& Hedenäs, 1991) and in Republic of Ireland, Netherlands and Finland by triangles (Koojiman \& Westhoff, 1995). Contains Ordnance Survey Data (C) Crown Copyright and database rights 2018. 


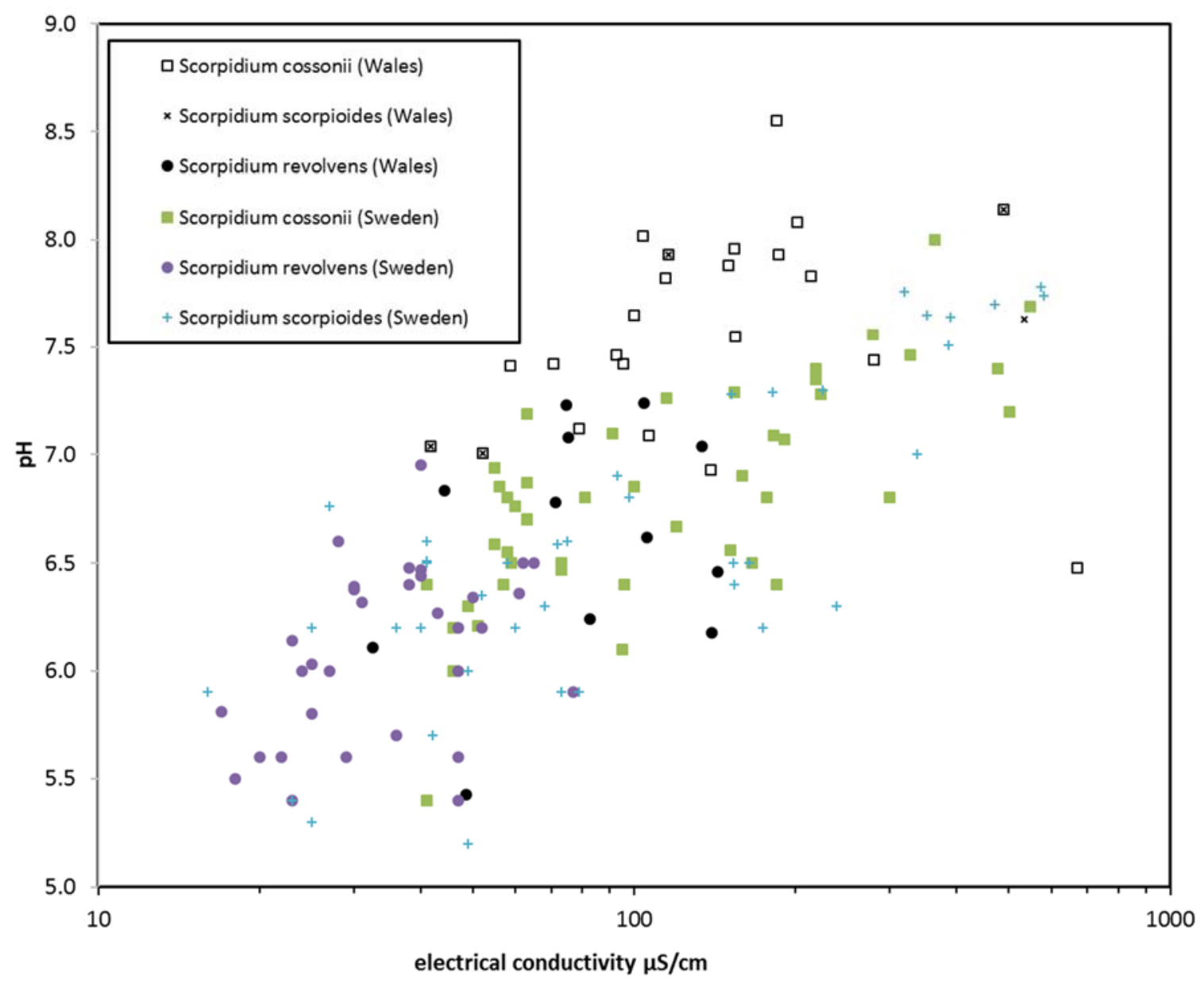

Figure 2 - Relationship between $\mathrm{pH}$ and EC between Welsh and Swedish analysis. Swedish data collected between 1990-1997 (from Kooijman \& Hedenäs 1991; plus unpublished data from different parts of Sweden by LH and A. Kooijman), Welsh data from 2014-2015. 
Table 1. Habitat preferences and geographical ranges for Scorpidium species based on Blockeel (2000) and Hedenäs (1999, 2003a, 2003b, 2014). IR (lonic Ratio), an indicator of water type $=2\left[\mathrm{Ca}^{2+}\right\} / 2\left[\mathrm{Ca}^{2+}\right)+[\mathrm{Cl}]$ (van Wirdum 1991).

\begin{tabular}{|c|c|c|c|c|c|c|c|}
\hline Species & $\begin{array}{c}\text { Altitude range } \\
\text { (m aOD) }\end{array}$ & Habitat & $\mathrm{pH}$ & $\underset{\substack{\mathrm{E} \\
(\mu \mathrm{s} / \mathrm{cm})}}{\mathrm{EC}}$ & $\begin{array}{c}\mathrm{Ca}^{2+} \\
(\mathrm{mg} / \mathrm{L})\end{array}$ & IR & Geographical range \\
\hline S. scompioides & $\begin{array}{l}\text { Global: } 0-5100 \\
\text { Sweden } 293 \text { (mean) } \\
\text { Wales } 398 \text { (mean) }\end{array}$ & $\begin{array}{l}\text { Calcium-rich fens } \\
\text { (pools \& lake shores) }\end{array}$ & $5.2-8.5$ & $14-582$ & $1.2-141.0$ & $0.34-1.00$ & $\begin{array}{l}\text { Widespread (often common) in temperate } \\
\text { to arctic areas of northern hemispheres } \\
\text { (and in the Andes and a few places in } \\
\text { Australia) }\end{array}$ \\
\hline S. cossoniï & $\begin{array}{l}\text { Global: } 0-4500 \\
\text { Sweden } 264 \text { (mean) } \\
\text { Wales } 362 \text { (mean) }\end{array}$ & $\begin{array}{l}\text { Calcium-rich fens (springs, } \\
\text { periodically water-filled } \\
\text { depressions \& lake shores) }\end{array}$ & $5.0-8.1$ & $18-681$ & $2.3-130$ & $0.42-1.0$ & $\begin{array}{l}\text { Widespread (often common) in temperate } \\
\text { to sub-polar areas of both hemispheres } \\
\text { (and in the Andes) }\end{array}$ \\
\hline
\end{tabular}

\section{Table 2}

Table 2. Comparison of EC, $\mathrm{pH}, \mathrm{Ca}^{2+}$, and $\mathrm{HCO}_{3}^{-}$in moss water of the three Scorpidium species in Wales and Sweden, respectively. Statistically significant differences between the areas are indicated by ${ }^{* *}: 0.01>p>0.001 ; * * *: p<0.001$.

\begin{tabular}{|c|c|c|c|c|c|c|c|c|c|}
\hline \multirow[b]{2}{*}{ Region } & \multirow[b]{2}{*}{ Species } & \multicolumn{2}{|c|}{$\mathrm{EC}, \mu \mathrm{S} \mathrm{\textrm {cm } ^ { - 1 }}$} & \multicolumn{2}{|c|}{$\mathrm{pH}$} & \multicolumn{2}{|c|}{$\mathrm{Ca}^{2+}, \mathrm{mg} \mathrm{L}^{-1}$} & \multicolumn{2}{|c|}{$\mathrm{HCO}_{3}, \mathrm{mg} \mathrm{L}^{-1}$} \\
\hline & & $\mathrm{N}$ & Mean (S.E.) & $\mathrm{N}$ & Mean (S.E.) & $\mathrm{N}$ & Mean (S.E.) & $\mathrm{N}$ & Mean (S.E.) \\
\hline Wales & S. cossoniï & 23 & $168(30)$ & 23 & $7.6(0.1)^{* * *}$ & 23 & $34.7(5.0)$ & 23 & 97 (14) \\
\hline Sweden & S. cossoniï & 44 & 150 (19) & 44 & $6.8(0.1)$ & 53 & $26.3(3.3)$ & 53 & $67(12)$ \\
\hline Wales & S. revolvens & 12 & $88(11)^{* * *}$ & 12 & $6.6(0.2)^{x *}$ & 13 & $7.2(2.0)$ & 13 & $18(6)$ \\
\hline Sweden & S. revolvens & 32 & $38(3)$ & 32 & $6.1(0.1)$ & 32 & $6.2(0.6)$ & 32 & $10(2)$ \\
\hline Wales & S. scorpioides & 6 & $223(92)$ & 6 & $7.5(0.2)^{n *}$ & 6 & $34.3(14.5)$ & 6 & $101(45)$ \\
\hline Sweden & S. scorpioides & 39 & $155(25)$ & 39 & $6.6(0.1)$ & 39 & $31.4(6.5)$ & 39 & $84(17)$ \\
\hline
\end{tabular}

\begin{tabular}{|c|c|c|c|c|c|c|}
\hline & \multicolumn{2}{|c|}{$\begin{array}{c}\text { Scorpidium cossonii } \\
(\mathrm{n}=\mathbf{2 3})\end{array}$} & \multicolumn{2}{|c|}{$\begin{array}{c}\text { Scorpidium revolvens } \\
(\mathrm{n}=12)\end{array}$} & \multirow{2}{*}{\begin{tabular}{|c|}
$\begin{array}{l}\text { Scorpidium cossonii - } \\
\text { Scorpidium revolvens }\end{array}$ \\
SE \\
\end{tabular}} & \multirow{2}{*}{\begin{tabular}{|c|}
$\begin{array}{l}\text { Scorpidium cossonii - } \\
\text { Scorpidium revolvens }\end{array}$ \\
$\mathrm{t}$ \\
\end{tabular}} \\
\hline & Av & SE & Av & SE & & \\
\hline $\mathrm{EC}, \boldsymbol{\mu S} / \mathbf{c m}$ & 167.50 & 30.17 & 88.02 & 10.87 & 14.54 & 5.78 \\
\hline $\mathrm{HCO}_{3}{ }^{-}, \mathrm{mg} / \mathrm{l}$ & 96.78 & 13.34 & 12.64 & 5.79 & 0.19 & 5.19 \\
\hline Ca, mg/l & 34.69 & 5.02 & 7.05 & 2.19 & 5.48 & 5.04 \\
\hline $\mathrm{Cl}^{-}, \mathrm{mg} / \mathrm{l}$ & 12.45 & 1.43 & 11.18 & 1.76 & 0.34 & 2.5 \\
\hline pH & 7.57 & 0.10 & 6.60 & 0.16 & 32.06 & 2.48 \\
\hline $\mathrm{Na}, \mathrm{mg} / \mathrm{l}$ & 6.82 & 0.74 & 6.75 & 1.09 & 1.15 & 1.55 \\
\hline $\mathrm{SO}_{4}{ }^{2-}, \mathrm{mg} / \mathrm{l}$ & 3.89 & 0.74 & 2.10 & 0.89 & 2.26 & 0.56 \\
\hline $\mathrm{SiO}_{2}, \mathrm{mg} / \mathrm{l}$ & 3.53 & 0.41 & 3.55 & 0.33 & 0.39 & 0.54 \\
\hline Mg, mg/l & 2.41 & 0.29 & 1.56 & 0.18 & 1.32 & 0.05 \\
\hline $\mathrm{K}, \mathbf{m g} / \mathbf{l}$ & 2.20 & 0.27 & 2.49 & 0.86 & 0.25 & -0.04 \\
\hline $\mathrm{Si}, \mathrm{mg} / \mathrm{l}$ & 1.65 & 0.19 & 1.66 & 0.15 & 0.52 & -0.04 \\
\hline $\mathrm{NO}_{3}^{-}, \mathrm{mg} / \mathrm{l}$ & 0.55 & 0.38 & 0.34 & 0.09 & 0.29 & -0.17 \\
\hline Mn, mg/l & 0.33 & 0.14 & 0.38 & 0.26 & 0.9 & -0.33 \\
\hline
\end{tabular}




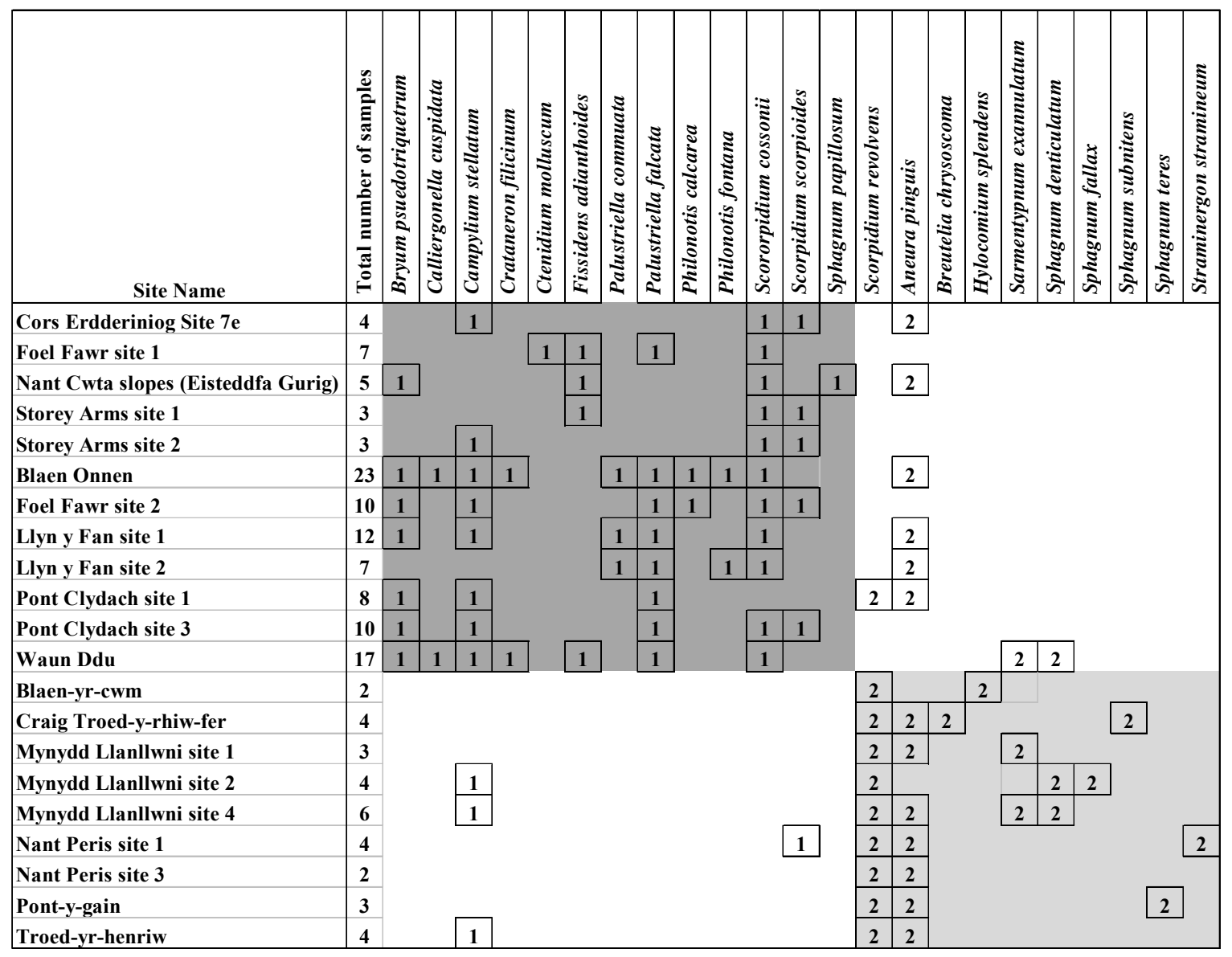

Table 5

\begin{tabular}{|c|c|c|c|c|c|c|c|c|c|c|c|c|c|c|}
\hline & \multirow{3}{*}{ pH } & & & & & & & & & & & & \\
\hline & & & EC & $\mathrm{Ca}$ & Mg & $\mathbf{N a}$ & $\mathbf{K}$ & $\mathrm{HCO}_{3}^{-}$ & $\mathrm{Cl}^{-}$ & $\mathrm{SO}_{4}{ }^{2-}$ & $\mathrm{NO}_{3}{ }^{-}$ & $\mathbf{S i}$ & $\mathrm{SiO}_{2}$ & Mn \\
\hline & & & $\mu \mathrm{S} / \mathrm{cm}$ & $\mathrm{mg} / \mathrm{l}$ & $\mathrm{mg} / 1$ & $\mathrm{mg} / \mathrm{l}$ & $\mathrm{mg} / \mathrm{l}$ & $\mathrm{mg} / 1$ & $\mathrm{mg} / 1$ & $\mathrm{mg} / \mathrm{l}$ & $\mathrm{mg} / \mathrm{l}$ & $\mathrm{mg} / \mathrm{l}$ & $\mathrm{mg} / \mathrm{l}$ & $\mathrm{mg} / \mathrm{l}$ \\
\hline \multirow{3}{*}{$\begin{array}{c}\text { Group } 1 \text { characterised by } \\
\text { Scorpidium cossonii }\end{array}$} & Min & 5.3 & 26 & 0.7 & 0.3 & 2.5 & 0.2 & 5 & 3.8 & 1 & 0.2 & 0.2 & 0.4 & 0 \\
\hline & Max & 11.8 & 787 & 98 & 9.7 & 113.7 & 7 & 261 & 201.4 & 17.6 & 9.2 & 5 & 10.6 & 11.7 \\
\hline & Mean & 7.5 & 197 & 35.2 & 2.8 & 11.2 & 2.2 & 101 & 19.6 & 4.4 & 0.8 & 1.8 & 3.9 & 0.5 \\
\hline \multirow{3}{*}{$\begin{array}{c}\text { Group } 2 \text { characterised by } \\
\text { Scorpidium revolvens }\end{array}$} & Min & 5.1 & 33 & 0.3 & 0.4 & 3.8 & 0.2 & 5 & 5.4 & 1 & 0.2 & 0.4 & 0.8 & 0 \\
\hline & Max & 7.2 & 143 & 26 & 2.7 & 16.1 & 10.7 & 68 & 23.2 & 10 & 1.3 & 4.4 & 9.5 & 0.4 \\
\hline & Mean & 6.3 & 79 & 5 & 1.4 & 6.4 & 2.3 & 10 & 10.2 & 3.6 & 0.7 & 1.7 & 3.5 & 0.1 \\
\hline
\end{tabular}

